\title{
Studi Komparatif Tindak Pidana Aborsi dalam Perspektif Hukum Positif dan Hukum Pidana Islam (Imam Madzhab)
}

\author{
Moh. Faqih ${ }^{1}$ \\ ${ }^{1}$ Fakultas Syariah, IAIN Jember. E-mail: mohfaqih6@gmail.com
}

\begin{tabular}{|c|c|}
\hline Article & Abstract \\
\hline $\begin{array}{l}\text { How to cite: } \\
\text { Moh. Faqih, ‘Studi } \\
\text { Komparatif Tindak } \\
\text { Pidana Aborsi dalam } \\
\text { Persepektif Hukum } \\
\text { Positif dan Hukum } \\
\text { Pidana Islam (Imam } \\
\text { Madzhab)' (2020) Vol. } 1 \\
\text { No. } 2 \text { Rechtenstudent } \\
\text { Journal Fakultas Syariah } \\
\text { IAIN Jember. } \\
\text { Histori artikel: } \\
\text { Submit } 24 \text { Mei 2020; } \\
\text { Diterima } 4 \text { Juli 2020; } \\
\text { Diterbitkan } 5 \text { Agustus } \\
\text { 2020. } \\
\text { ISSN: } \\
\text { 2723-0406 (media cetak) }\end{array}$ & 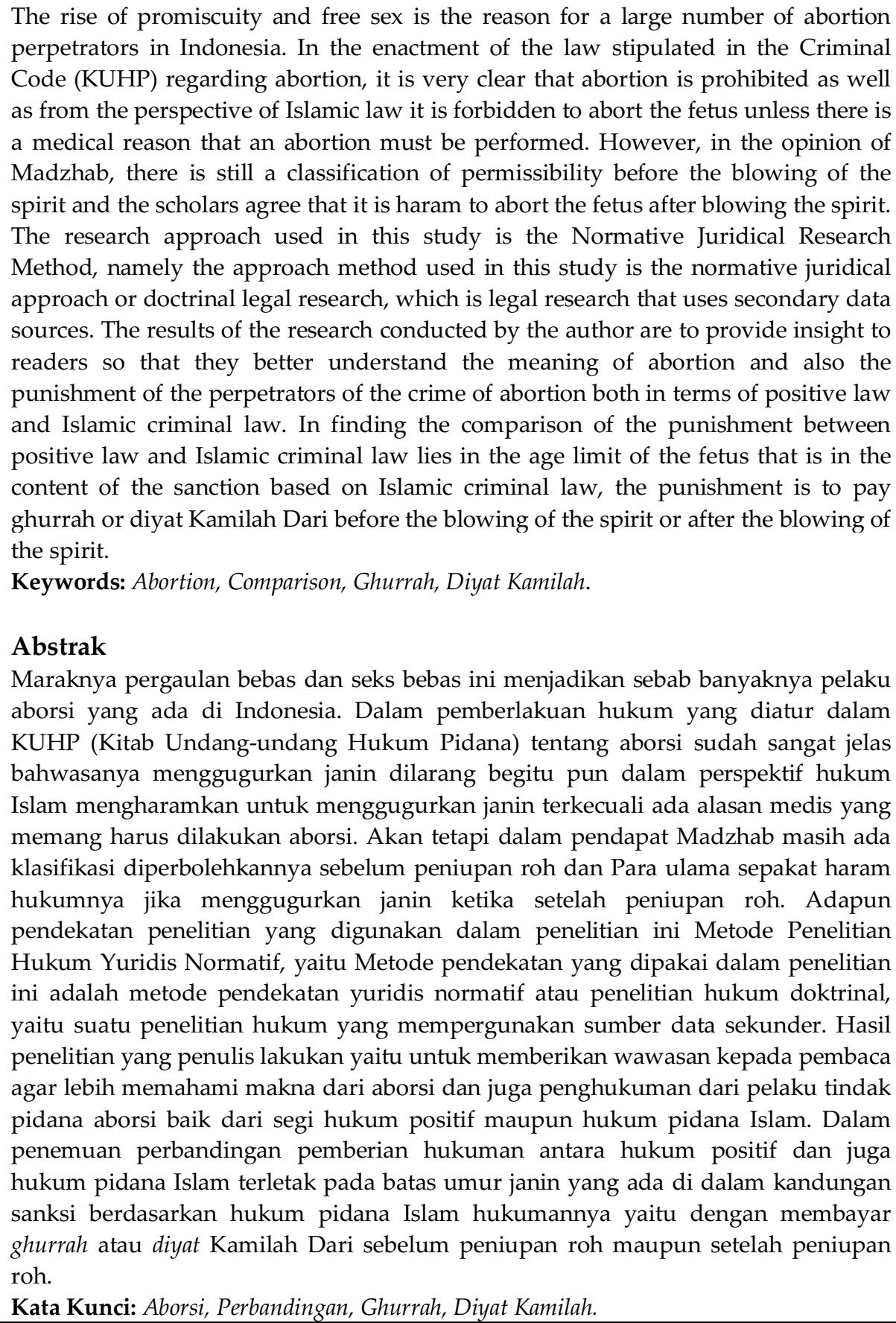 \\
\hline
\end{tabular}




\section{Pendahuluan}

Perlu diketahui berdasarkan undang-undang dasar 1945 dijelaskan pada pasal 28 A yang berbunyi setiap orang berhak untuk hidup serta berhak mempertahankan hidup dan kehidupannya. Artinya setiap manusia terutama warga Negara Indonesia, sejak lahir mempunyai hak yang sama dalam hal hak untuk hidup dan mempertahankan kehidupannya. ${ }^{1}$ Tidak ada satu orang pun yang bisa membeli nyawa orang lain atau menghilangkan nyawa orang lain dengan alasan apapun. Apabila ada yang melawan hukum yaitu dengan merampas nyawa orang lain dengan berbagai alasan maka pelaku akan tetap harus menanggung hukuman dengan aturan yang telah ditetapkan.

Jadi setiap tindakan maupun perilaku setiap warga Negara Indonesia ada batasan tersendiri dengan tujuan untuk tidak berperilaku semena-mena dan menjunjung kesejahteraan. Setiap Hak Asasi manusia di Indonesia memang sangat diperhatikan sekali karna selain menjaga jiwa individu atau kelompok. Tidak hanya itu janin yang ada di dalam kandungan pun memiliki hak untuk hidup.

Melihat realita yang ada pada saat ini, banyak remaja menggugurkan kandungannya. Dengan alasan bayi yang ada didalam kandungannya tidak dikehendaki sehingga sang ibu menggunakan cara aborsi untuk menggugurkan bayi tersebut. Tidak hanya itu sebab maraknya aborsi selain dari kenakalan remaja yang saat ini banyak sekali terjadi di sekitar.

Data PKBI pada 2016 menyebut jumlah perempuan hamil sebanyak 4.857 hamil tak diinginkan yang mengakses layanan konseling KTD. Dari total pengakses layanan konseling KTD, $76,1 \%$ adalah yang terikat status pernikahan, sementara hanya $23,9 \%$ pengakses yang tidak atau belum menikah.

Mereka mengakses layanan KTD berbasis konseling lantaran telah cukup punya anak $(44,9 \%)$, memiliki anak yang masih kecil $(12,5 \%)$, dan tidak/belum menikah $(11,1 \%)$. Sisanya menyangkut alasan kondisi kesehatan yang tidak memungkinkan $(2,2 \%)$, korban perkosaan $(0,5 \%)$, tidak mau bertanggung jawab atas kehamilan yang diperbuat $(2,6 \%)$, dan pengakses layanan gagal KB (0,5\%). Data PKBI itu menunjukkan pasangan sudah menikah yang paling banyak mengakses layanan KTD berbasis konseling. Ini menjungkirkan asumsi populer masyarakat bahwa yang mengakses layanan kehamilan tak diinginkan adalah anak muda tanpa ikatan pernikahan.

Kondisi perempuan sulit mengakses layanan KTD umum terjadi di Indonesia. Perempuan menjadi korban berlapis, penanggung beban utama dalam kasus kehamilan yang tidak diinginkan. Sementara, undang-undang di Indonesia belum berpihak kepada mereka. Pemberian informasi yang komprehensif terhalang minimnya pendidikan kesehatan seksual dan reproduksi serta hambatan tabu informasi tentang mengenai seksualitas. Kondisi ini sempat terjadi pada kasus Gemma, sebagaimana cerita di atas. Ia akhirnya melakukan aborsi aman di Thailand karena ada hambatan dalam mengakses informasi dan layanan di Indonesia, termasuk di antaranya prasyarat yang menyulitkan akses layanan. ${ }^{2}$

Perdebatan mengenai aborsi di Indonesia akhir-akhir ini semakin ramai karena dipicu oleh berbagai peristiwa yang mengguncang sendi-sendi kehidupan manusia. Kehidupan yang diberikan kepada setiap manusia merupakan Hak Asasi Manusia hanya boleh dicabut oleh pemberi kehidupan. Berbicara mengenai aborsi tentunya berbicara tentang kehidupan

\footnotetext{
1 Pasal 28A Undang-Undang Dasar 1945.

${ }^{2}$ Http://Www.Google.Com/Amp/S/Amp.Tirto.Id/Sangat-Penting-Mendapatkan-Layanan-Aborsi-Aman-Dhmt
}

(Diakses Pada Tanggal 17 April 2020). 
manusia karena aborsi erat kaitannya dengan wanita dan janin yang ada di dalam kandungan wanita.

Aborsi selalu menjadi perbincangan, baik dalam forum resmi maupun tidak resmi yang menyangkut materi bidang kedokteran, hukum maupun disiplin ilmu lainnya. Aborsi merupakan fenomena sosial yang semakin memprihatinkan. Keprihatinan itu bukan tanpa alasan, sejauh ini pengguguran kandungan (Aborsi) masih banyak menimbulkan efek negatif baik untuk diri pelaku maupun pada masyarakat luas. Hal ini disebabkan karena aborsi menyangkut norma moral serta hukum suatu kehidupan bangsa. Aborsi telah dikenal sejak lama, aborsi memiliki sejarah panjang dan telah dilakukan oleh berbagai metode baik itu natural atau herbal, penggunaan alat-alat tajam, trauma fisik dan metode tradisional lainnya.

Pada zaman saat ini dalam pengguguran kandungan (Aborsi) bisa memanfaatkan obatobatan dan prosedur operasi teknologi tinggi dalam melakukan aborsi. Legalitas, normalitas, budaya dan pandangan mengenai aborsi secara substansial berbeda di seluruh negara. Di banyak Negara didunia, isu aborsi adalah permasalahan menonjol dan memecah belah publik atas atas kontroversi etika dan hukum.

Dalam studi Hukum Islam terdapat perbedaan pendapat tentang aborsi di dalam empat fiqih mazhab. Imam Hanafi misalnya yang menjadi madzhab yang paling fleksibel memandang bahwa, sebelum empat bulan masa kehamilan, aborsi bisa dilakukan apabila mengancam kehidupan perempuan yang sedang mengandung Mazhab Maliki melarang aborsi setelah terjadinya pembuahan Mazhab Syafi'i memandang bahwa apabila setelah terjadi vertilasi zygote tidak boleh diganggu, dan intervensi terhadapnya adalah sebagai kejahatan sedangkan Mazhab Hambali menegaskan dengan keras bahwa aborsi adalah dosa, dengan adanya pendarahan yang menyebabkan keguguran sebagai petunjuk bahwa aborsi itu haram.

Dalam pandangan Hukum Pidana Islam aborsi dan juga fukaha ada yang memperbolehkan aborsi dan ada juga yang tidak memperbolehkan. Menurut Imam al-Ramli dari kelompok pengikut Imam Syafi'i, melakukan aborsi bagi janin yang sudah berusia 120 hari, haram hukumnya. Karena diperkirakan bahwa janin sudah bernyawa. Bagi yang melakukannya maka sangsinya adalah ghurrah, yakni diyat yang harus dipenuhi oleh orang yang melakukan pembunuhan janin, berupa membayar seorang budak laki-laki atau perempuan kepada keluarga janin atau membayar kafarat senilai dengan seperdua puluh diyat biasa, yaitu lima ekor unta. Sedangkan pengguguran sebelum 120 hari hukumnya boleh berdasarkan beberapa pendapat ulama. ${ }^{3}$

\section{Rumusan Masalah}

Adapun rumusan masalah dalam penelitian ini adalah:

1. Bagaimana aborsi dalam pandangan Hukum Positif?

2. Bagaimana aborsi dalam pandangan Hukum Pidana Islam?

3. Bagaimana perbandingan pemberian hukuman terhadap pelaku aborsi dalam perspektif Hukum Positif dan Hukum Pidana Islam?

\footnotetext{
${ }^{3}$ Syihâbuddin Al-Ramli, Nihâyat Al-Mukhtaj, Syarh Alminhaj Fî Al-Figh' Alâ Madzhab Al-Lmam Syafi'i, Jilid VII, (Alhalabi, 1357 H), 416.
} 


\section{Metode Penelitian}

Penelitian hukum merupakan suatu kegiatan ilmiah berdasarkan metode dan pemikiran tertentu, dengan jalan menganalisisnya dan mengadakan pemeriksaan mendalam terhadap fakta hukum tersebut. untuk kemudian mengusahkan suatu pemecahan atas permasalahanpermasalahan yang timbul dalam gejala yang bersangkutan. ${ }^{4}$

Metode yang diterapkan penulis di dalam penulisan ini yaitu Metode Penelitian Hukum Yuridis Normatif, yaitu Metode pendekatan yang dipakai dalam penelitian ini adalah metode pendekatan yuridis normatif atau penelitian hukum doktrinal, yaitu suatu penelitian hukum yang mempergunakan sumber data sekunder. Dilakukan dengan menekankan dan penelitian kepustakaan, yaitu penelitian terhadap data sekunder. Data sekunder mempunyai ruang lingkup yang meliputi surat-surat pribadi, buku-buku, sampai pada dokumen-dokumen resmi yang dikeluarkan oleh pemerintah. ${ }^{5}$ Pendekatan normatif ini akan dititik beratkan pada masalah yuridis mengenai aturan-aturan hukum. ${ }^{6}$

\section{Pandangan Aborsi dalam Perspektif Hukum Positif}

Dalam Bahasa Inggris abortus Disebut abortion, berasal dari bahasa latin yang berarti gugur kandungan Dalam Ensiklopedia dijelaskan bahwa sebelum masa gestasi 28 minggu atau janin mencapai beras seribu gram. Menurut Sardikin Ginaputran abortus ialah pengakhiran kehamilan atau hasil konsepsi sebelum janin dapat hidup di luar kandungan.

Sedangkan menurut Maryono Reksodipuro Abortus ialah pengeluaran hasil konsepsi dari Rahim sebelum waktunya (sebelum dapat lahir secara alamiah). Dari beberapa pengertian di atas dapat dikatakan bahwa abortus adalah suatu perbuatan untuk mengakhiri masa kehamilan dengan mengeluarkan janin dari kandungan sebelum tiba masa kelahiran secara alami.

Untuk terjadinya abortus setidaknya ada tiga unsur yang harus dipenuhi, yaitu sebagai berikut:

1. Adanya embrio (janin) yang merupakan hasil pembuahan antara sperma dan ovum dalam Rahim.

2. Pengguguran terjadi karena sendirinya, tapi lebih sering disebabkan perbuatan manusia.

3. Keguguran itu terjadi sebelum waktunya, artinya sebelum masa kelahiran tiba.

Abortus ada dua macam, yaitu sebagai berikut:

1. Abortus spontan (spontaneous abortus) ialah abortus yang tidak disengaja. ${ }^{7}$ Abortus spontan bisa terjadi karena penyakit sifilis, kecelakaan dan lain sebagainya.

2. Abortus yang disengaja (abortus provocatus/ induced pro abortion) abortus ini terjadi karena dua macam yaitu sebagai berikut:

a. Abortus artuficialis therapicus ialah abortus yang dilakukan oleh dokter atas dasar indikasi media. Misalnya jika kehamilan diteruskan bisa membahayakan jiwa si calon $\mathrm{ibu}$, karena misalnya penyakit-penyakit yang berat, antara lain TBC yang berat dan penyakit ginjal yang berat.

\footnotetext{
${ }^{4}$ Beni Ahmad Saebani, Metode Penelitian Hukum (Bandung: CV Pustaka Setia, 2009), 32.

5 Soerjono Soekanto Dan Sri Mamudji, Penelitian Hukum Normatif Suatu Tinjauan Singkat, Cetakan Kedelapan, (Jakarta. Sinar Grafika, 2004), 24.

${ }^{6}$ Rianto Adi, Metodologi Penelitian Sosial Dan Hukum, (Jakarta: Granit, 2004), 72.

${ }^{7}$ Cecep Wibowo, Etika dan Hukum Kesehatan, (Yogyakarta: Nuha Medika, 2014), 168
} 
b. Abortus Provocatus criminls ialah dilakukan tanpa dasar indikasi medis. Misalnya abortus yang dilakukan untuk meniadakan hasil hubungan seks di luar perkawinan atau untuk mengakhiri kehamilan yang tidak dikehendaki. ${ }^{8}$

Adapun tindak pidana aborsi atau menggugurkan kandungan telah diatur dalam hukum positif yaitu KUHP pasal 346, 347, 348,349,350 yang berbunyi:

Pasal 346 :

Seorang wanita dengan sengaja menggugurkan atau mematikan kandungan atau menyuruh orang lain untuk itu, diancam dengan pidana penjara paling lama empat tahun

\section{Pasal 347}

(1) Barang siapa dengan sengaja menggugurkan atau mematikan kandungan serang wanita tanpa persetujuannya, diancam dengan pidana penjara paling lam dua belas tahun

(2) Jika perbuatan itu mengakibatkan kematian wanita tersebut diancam dengan pidana penjara paling lama lima belas tahun

\section{Pasal 348}

(1) Barang siapa dengan sengaja menggugurkan atau mematikan kandungan seorang wanita dengan persetujuannya, diancam dengan pidana penjara paling lama lima tahun enam bulan.

(2) Jika perbuatan itu mengakibatkan matinya wanita tersebut, diancam dengan pidana penjara paling lama tujuh tahun.

\section{Pasal 349}

Jika seorang dokter, bidan atau juru obat membantu melakukan kejahatan berdasarkan 346 ataupun melakukan atau membantu melakukan salah satu kejahatan yang diterangkan dalam pasal 347 dan 348, maka pidana yang ditentukan dalam pasal itu dapat ditambah dengan sepertiga dan dapat dicabut hak menjalankan pencarian dalam mana kejahatan dilakukan.

\section{Pasal 350}

Dalam hal pemidanaan karena pembunuhan dengan rencana, atau karena salah satu kejahatan berdasarkan pasal 344, 347 dan 348, dapat dijatuhkan pencabutan hak pasal 35 No $1-5^{9}$

\section{Pandangan aborsi dalam Hukum Pidana Islam}

Aborsi adalah berakhirnya kehamilan dapat terjadi secara spontan akibat kelainan fisik wanita atau akibat penyakit biomedis internal atau mungkin disengaja melalui campur tangan manusia. Menggugurkan kandungan yang dalam bahasa arabnya Ijhaadh, merupakan bentuk masdar dari ajhadha yang artinya wanita yang melahirkan anaknya secara paksa dalam keadaan belum sempurna penciptaannya. ${ }^{10}$

Secara bahasa bisa dikatakan lahirnya janin karena dipaksa atau karena lahir atas dengan sendirinya. Sedangkan makna menggugurkannya kandungan menurut fuqaha tidak keluar jauh dari makna lughawiyahnya, tetapi kebanyakan mengungkapkan masalah ini

\footnotetext{
8 Ibid., 153-155.

${ }^{9}$ KUHAP (Kitab Undang-Undang Hukum Acara Pidana dan KUHP (Kitab Undang-Undang Hukum Pidana, (Efata Publishing, 2016), 273-274.

${ }^{10}$ Ibid., 125.
} 
dibeberapa tempat dengan istilah arab Isqath (menjatuhkan) Tharh (membuang) Ilqa' (melempar) Imlaash (melahirkan dalam keadaan mati).

Dalam pembahasan ini, pengertian pengguguran kandungan dibatasi pada lahirnya janin atau umur janin karena dipaksa oleh ibunya atau dipaksa oleh orang lain atas permintaan dan kerelaan. Mengenai hukum menggugurkan kandungan ini tidak ada nash secara langsung menyebutkannya, baik alqur'an maupun hadits. Sedangkan yang dijelaskan dalam kitab Allah Azza Wa Jalla adalah tentang haramnya membunuh orang tanpa hak, mencela perbuatan itu dan menghukum pelakunya dengan hukuman yang abadi dineraka jahanam. Allah SWT berfirman:

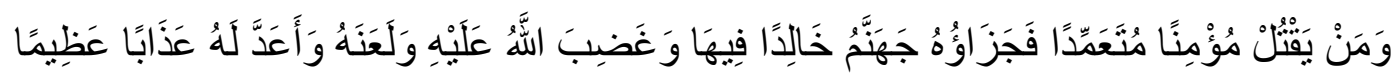

“Dan barang siapa yang membunuh seorang mukmin dengan sengaja maka balasannya ialah jahanam dan ia kekal di dalamnya Allah murka kepadanya dan mengutuknya serta menyediakan azab yang besar baginya". (An-Nisa': 93) ${ }^{11}$

Seperti juga dijelaskan di dalam Al Qur'an tentang tahap-tahap penciptaan manusia, bahwa masuknya roh adalah dasar penciptaannya. Dengan masuknya roh ke dalam jasad, maka terjadilah kehidupan manusiawi dan dengan keluarnya roh darinya, maka habislah kehidupan manusia di dunia.

Begitu juga di dalam Hadits-hadits Rasulullah SWT, dijelaskan tentang tahap-tahap penciptaan manusia dalam perut ibunya dan membatasi masa masing-masing tahapan tersebut. Serta sewaktu-waktu peniupan roh di dalam jasad manusia. di dalam sebuah hadits yang dianggap paling benar, baik dari segi matan maupun sanadnya yaitu hadits yang diriwayatkan oleh Al Bukhari dan Muslim dari Ibnu Mas'ud. Rasulullah SWT Bersabda:

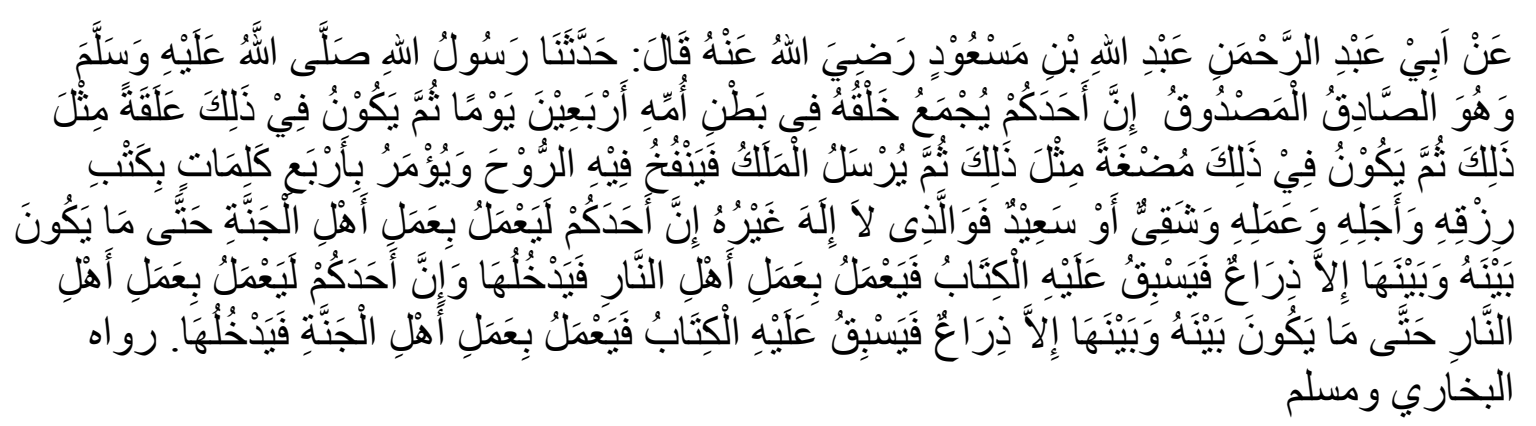

Kejadian seseorang itu dikumpulkan dalam perut ibunya selama empat puluh hari. Setelah genap empat puluh hari kedua, terbentuklah segumpal darah beku, mana kala genap empat puluh hari ketiga berubahlah menjadi segumpal daging. Kemudian Allah SWT mengutus malaikat untuk meniupkan roh serta memerintahkan supaya menulis empat perkara yaitu ditentukan rezeki, waktu kematian, amal serta nasibnya, baik mendapat kecelakaan atau kebahagiaan. ${ }^{12}$

Ada pula beberapa hadits yang menjelaskan tentang denda harus dibayarkan karena menggugurkan janin, denda itu Rasulullah SWT disebut dengan Ghurrah (budak). Dalam penghukuman pelaku aborsi masih dalam polemik karna tidak ada ayat yang mengatur

\footnotetext{
${ }^{11} \mathrm{Al}$ Qur'an, 4:93

12 Muhammad Nu'aim Yasin, Fikih Kedokteran (Jakarta: Darus-Salam, 2003), 193-195.
} 
secara langsung terkait aborsi, akan tetapi para fuqaha berijtihad untuk membuat hukum yang akan mengatur tentang aborsi dengan mengaitkan nash-nash dan syariat Islam.

\section{Pandangan Aborsi menurut Imam Madzhab}

Dalam mengemukakan pendapat para fuqaha menukil beberapa alasan tersebut, adanya perbedaan pendapat di dalam satu madzhab karena mengisbatkan pendapat kepada suatu madzhab tertentu tidak mendetail dengan menukil beberapa pendapat fuqaha dari dalam satu madzhab. Para fuqaha islam telah sepakat dalam menetapkan hukum menggugurkan kandungan setelah peniupan roh . adapun sebagian besar perbedaan di antara mereka adalah mengenai pengguguran jenis sebelum peniupan roh.

\section{a. Hukum Pengguguran Janin Setelah Peniupan Roh}

Para Fuqaha sepakat atas haramnya pengguguran janin setelah janin berusia empat bulan di dalam perut ibunya. Karena pada usia itu telah ditiupkan roh kepadanya, seperti yang diberitakan Rasulullah SWT di dalam hadis yang disebutkan di atas. Seorang janin, jika ditiupkan roh kepadanya akan menjadi manusia tidak boleh dibunuh karena tidak ada sebab syar'i. padahal tidak ada satu pun sebab-sebab syar'i yang membolehkan pengguguran janin pada fase itu.

Makna zhahir dari pendapat para fuqaha menunjukkan bahwa mereka mengharamkan pengguguran kandungan setelah peniupan roh, apabila keberadaan janin membahayakan ibunya. Bahkan sebagian mereka mengatakan secara terus terang seperti Ibnu Najib Al-Hanafi mengatakan, "seorang wanita hamil yang terancam bahaya karena anak yang ada di dalam perutnya, anaknya tidak boleh digugurkan, tetapi jika anaknya sudah mati di dalam perut tidak apa-apa digugurkan. Dan apabila janin masih hidup, tidak diperbolehkan karena menghidupkan seorang jiwa dengan membunuh jiwa lain tidak diperkenankan di dalam syariat" ${ }^{13}$

Ibnu Abidin Juka memberikan pendapat “tidak boleh digugurkan, karena kematian ibunya masih diragukan, maka tidak boleh membunuh manusia yang hidup karena perkara yang meragukan. Belum menemukan teks-teks fiqih yang berbeda pendapat dengan masalah ini, karna hukum dasarnya adalah bahwa membunuh jiwa diharamkan dalam syariat tidak diperbolehkan hukumnya dengan alasan apapun. Allah SWT Berfirman:

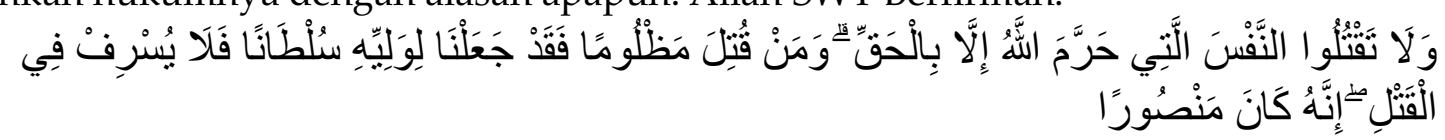

“Dan janganlah kamu membunuh jiwa yang diharamkan Allah (Membunuhnya), melainkan dengan (alasan) yang benar dan barang siapa dibunuh secara zalim maka sungguh kami telah memberi kekuasaan kepada walinya tetapi janganlah walinya itu melampaui batas dalam pembunuhan sesungguhnya dia adalah orang yang mendapatkan pertolongan". (Al Isra': $33)^{14}$

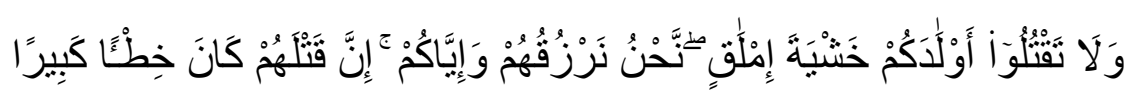

${ }^{13}$ Ibid., 195-198

${ }^{14} \mathrm{Al}$ Qur'an, 17: 33 
"Dan janganlah kamu membunuh anak-anakmu karena takut kemiskinan. Kamilah yang akan memberi rezeki kepada mereka dan juga kepadamu. Sesungguhnya membunuh mereka adalah suatu dosa yang besar". (Surah Al Isra': 31$)^{15}$

Jadi tidak boleh membunuh jiwa yang suci untuk menyelamatkan jiwa orang lain, dan tidak halal bagi orang yang tidak mau mati lalu membunuh orang lain, walaupun dalam keadaan terpaksa. Para fuqaha tidak berselisih pendapat tentang masalah ini. Dan menurut jumhur ulama bahwa membunuh karena terpaksa harus dihukum Qishash. Dari pendapat Fuqaha dalam masalah pengguguran janin dapat disimpulkan bahwasannya pengguguran janin di saat roh sudah ditiupkan ke janin tidak diperbolehkan.

Pertama tidak diwajibkan Qishash bagi ibu apabila membunuh janin, walaupun disengaja dan direncanakan. Di antara alasan Fuqaha kemukakan untuk menetapkan hukum ini adalah karena asal telah dijadikan oleh Allah sebagai sebab untuk mewujudkan cabang. Maka tidak layak jika cabang menjadi sebab kematian asalnya.

Kedua sebagian besar fuqaha sepakat bahwa pembunuh janin tidak diqishash walaupun disengaja, walaupun janinnya lahir dalam keadaan mati, dan walaupun pekerjaan itu haram hukumnya. Dari pendapat kedua fuqaha dapat disimpulkan bahwa kehormatan ibu lebih tinggi dari pada kehormatan janin jika keduanya bertemu. Maka tidak ada jalan lain kecuali mengorbankan salah satu jiwa untuk menyelamatkan jiwa yang lain.

\section{b. Hukuman Pengguguran Janin Sebelum Peniupan Roh}

Beberapa Madzhab Fiqih berbeda pendapat tentang hukum menggugurkan janin yang usianya belum sapai empat bulan atau belum ditiupkan roh kepadanya. Banyak sekali perbedaan pendapat diantara madzhab-madzhab, bahkan dalam satu ulama dalam satu madzhab pun juga berselisih pendapat. Dari ke empat madzhab mengemukakan pendapat terkait penghukuman pengguguran janin antara lain sebagai berikut:

1) Madzhab Hanafi

Para Fuqaha dari madzhab Hanafi memperbolehkan pengguguran kandungan atau janin sebelum peniupan roh asalkan mendapatkan izin dari kedua orang tua dan yang bersangkutan. Ibnu Al Hammam berkata, "bolehkah menggugurkan janin setelah kehamilan. Diperbolehkan sebelum terbentuk apapun pada janin". ${ }^{16}$

2) Madzhab Maliki

Para ulama madzhab maliki secara mutlak melarang aborsi. Seperti yang lain-lain mereka ini juga berpendapat janin bukanlah manusia sebelum ditiupkan ruh kepadanya. Kendati begitu karena sperma sekali dituangkan dan terwadahi, ditumbuhkan dan ditentukan untuk kemudian mendapatkan ruhnya, maka janin harus dilindungi sepenuhnya.

3) Madzhab Syafi'i

Pendapat yang telah dikemukakan bahwa dalam pengguguran janin atau kandungan sebelum ditiupkannya roh kepada janin diperbolehkan.

\footnotetext{
${ }^{15}$ Ibid., 17: 31

${ }^{16}$ Muhammad Bin 'Arafah Al-Dasuqi, Hasiyyah Al-Dasuki Ala Al-Syarah Al-Kabir, Juz II, (Bayrut: Dar Al-Fikr, T.T.), H. 266-267.
} 
4) Madzhab Hambali

Secara umun pendapat secara umum dalam madzhab memperbolehkan menggugurkan kandungan pada fase perkembangan pertama sejak terbentuknya janin. ${ }^{17}$

Jika air mani telah tinggal dalam Rahim, maka tidak halal untuk menggugurkan janin yang telah berumur 120 hari. Sebab pada saat itu dipandang sebagai merusak jiwa yang dapat dikenai hukuman di dunia dan di akhirat. Adapun menggugurkan janin atau merusak benih sebelum masa tersebut ini lewat, dibolehkan jika ada alasan-alasan yang sah untuk itu. Jika tidak ada alasan-alasan yang benar maka hukumannya makruh.

\section{Kesimpulan}

Aborsi merupakan tindakan dilarang berdasarkan KUHP yang berlaku di Indonesia yang sudah tercantum dalam Pasal 346, 347, 348, 349 sangat melarang aborsi atau menggugurkan janin yang ada dalam kandungan. Karena janin di dalam kandungan mempunyai hak untuk hidup dan wajib dihormati. Apabila melanggar maka akan dikenakan hukuman yang telah ditentukan dan masuk kategori pasal yang mana. Akan tetapi berdasarkan Undang-Undang No. 36 Tahun 2009 tentang Kesehatan Janin dapat di gugurkan apabila ada alasan medis yang resmi. Seperti dengan keadaan janin yang ada di dalam kandungan tersebut mengancam nyawa sang ibu. Jadi aborsi bisa dilakukan asalkan dengan alasan medis.

Pengguguran kandungan pada prinsipnya dilarang, tetapi dengan keadaan tertentu bisa dilakukan berdasarkan alasan yang dibenarkan secara medis. Akan tetapi ada beberapa pendapat ulama madzab yang memperbolehkan dan melarang pengguguran sebelum usia kandungan 120 hari. Dari Madzhab Maliki, Syafi'I dan Hanafi melarang pengguguran kandungan, dan sebaliknya Hanbali memperbolehkan aborsi sebelum usia janin 120 hari. dan setelah usia kandungan lewat dari 120 hari pendapat madzhab melarang apabila melanggar melakukan aborsi tersebut maka mendapatkan hukuman Membayar Ghurrah atau diyat kamilah tergantung keluarnya bayi setelah aborsi.

Dalam perbandingan antara hukum positif dengan hukum pidana Islam pengguguran kandungan atau aborsi ini merupakan suatu tindak pidana atau jinayah. Adapun dalam hukum positif aborsi dilarang semenjak ada pembuahan dalam janin. Maka secara tidak langsung janin yang sudah masa pembuahan itu jika ditarik dalam hukum positif mempunyai hak untuk hidup, jadi aborsi dilarang dan dikenakan sanksi berupa hukuman yang telah diatur dalam Pasal 346, 347, 348, 349 KUHP. Sedangkan dalam perspektif hukum pidana islam aborsi masih ada perdebatan antara ulama satu dengan yang lain apabila janin masih belum berumur 120 hari atau sebelum ditiupkannya roh. Di situ masih ada yang memperbolehkan seperti Madzhab Hanafi akan tetapi dengan alasan-alasan yang rasional. Dan apabila ada salah satu melanggar berdasarkan hukum islam ada dua macam penghukuman. Jika bayi yang digugurkan sudah dalam keadaan mati maka hukumannya membayar Ghurrah. Sedangkan apabila bayi digugurkan itu hidup lalu mati maka hukumannya membayar diyat kamilah.

\footnotetext{
${ }^{17}$ Ahsin W Al-Hafidz, Fikihkesehatan (Jakarta: Amzah, 2007), 162
} 


\section{Daftar Pustaka}

\section{Buku}

Al Qur'an.

Adi, Rianto. 2004. Metodologi Penelitian Sosial dan Hukum. Jakarta: Granit.

Al-Hafidz, Ahsin W. 2007. Fikih Kesehatan. Jakarta: Amzah.

Al-Ramli, Syihabuddin. Nihâyat Al-Mukhtaj, Syarh Alminhaj Fî Al-Fiqh' Alâ Madzhab Al-Lmam Syafi'i, Jilid VII. (Alhalabi, $1357 \mathrm{H}$ ).

Muhammad Bin 'Arafah Al-Dasuqi, Hasiyyah Al-Dasuki Ala Al-Syarah Al-Kabir, Juz II, (Bayrut: Dar Al-Fikr, T.T.).

Saebani, Beni Ahmad. 2009. Metode Penelitian Hukum. Bandung: CV. Pustaka Setia.

Soekanto, Soerjono Dan Sri Mamudji. 2004. Penelitian Hukum Normatif Suatu Tinjauan Singkat. Cetakan Kedelapan Jakarta. Sinar Grafika.

Wibowo, Cecep. 2014. Etika dan Hukum Kesehatan. Yogyakarta: Nuha Medika.

Yasin, Muhammad Nu'aim. 2003. Fikih Kedokteran. Jakarta: Darus-Salam.

\section{Perundang-undangan}

Undang-Undang Dasar Negara Republik Indonesia 1945.

KUHAP (Kitab Undang-Undang Hukum Acara Pidana dan KUHP (Kitab Undang-Undang Hukum Pidana. (Efata Publishing, 2016).

\section{Laman}

http://Www.Google.Com/Amp/S/Amp.Tirto.Id/Sangat-Penting-Mendapatkan-LayananAborsi-Aman-Dhmt. 